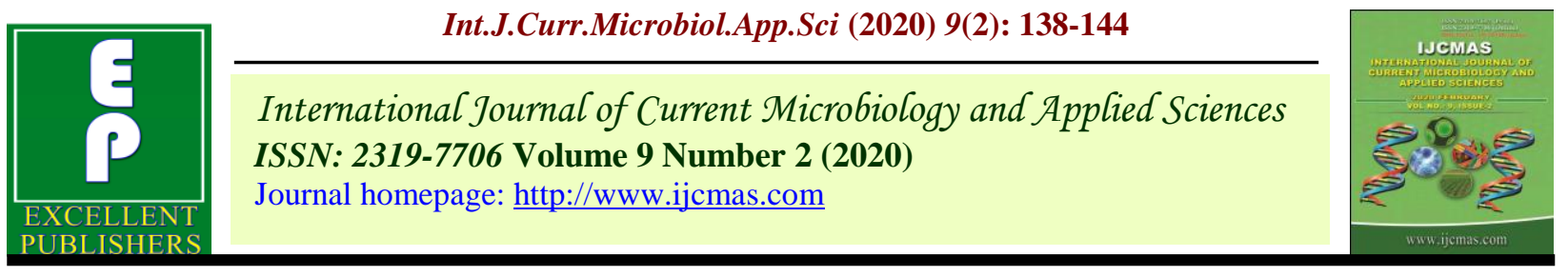

Original Research Article

https://doi.org/10.20546/ijcmas.2020.902.017

\title{
Selection of Parents based on Combining Ability Studies in Okra (Abelmoschus esculentus L. moench)
}

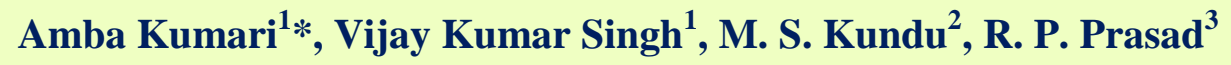 \\ ${ }^{1}$ Department of vegetable science, Bihar Agricultural University, \\ Sabour (Bhagalpur) - 813210, Bihar, India \\ ${ }^{2}$ Extension Education, RAU, Pusa (Samastipur) - 843121, Bihar, India \\ ${ }^{3}$ Department of plant protection, KVK (Darbhanga)-847302, India \\ *Corresponding author
}

\section{Keywords}

Abelmoschus esculentus L. Moench, Combining ability, gca effects, sca effects

Article Info

Accepted:

05 January 2020 Available Online: 10 February 2020

\section{A B S T R A C T}

Okra or lady's finger, (Abelmoschus esculentus L. Moench) commonly known as bhindi in India is the most popular vegetable of the family malvaceae, is an important vegetable of the tropical and subtropical region. It is valued for its medicinal properties to cure renal colic, leucorrhoea, chronic dysentery and goitre due to high iodine content in fruits. In okra, a large number of varieties have been developed but substantial increase in productivity could not be realized. There is a necessary to improve the yield per unit area to achieve the increased production from a limited land. The experiment was undertaken to study the combining ability for yield and its contributing traits in okra. The experimental material consisted of 30 genotype ( 7 parents, 2 standard checks 21 F1 hybrids) was conducted in a randomized block design for fifteen characters. The mean square due to gca (General combining ability), sca (Specific combining ability) effects were significant for pod yield and yield contributing traits studied. The parents KashiKranti, ArkaAbhay and PusaSawani were found to be best general combiner for most of the characters including yield per plant and can be exploited well in further breeding programme. The estimates of effects revealed that the cross combinations ArkaAbhay x KashiKranti, KashiPragati x PusaSawani,ArkaAbhay x Punjab Padmini,PunjabPadmini x PusaSawani and ArkaAnamika x KashiKranti exhibited positive significant effect for yield attributing character and some of its related traits could be used as heterotic hybrids.

\section{Introduction}

Okra or lady's finger, (Abelmoschus esculentus L. Moench) commonly known as bhindi in India is the most popular vegetable of the family malvaceae. It is valued for its medicinal properties to cure renal colic, leucorrhoea; chronic dysentery and goitre due to high iodine content in fruits. The dried stems of okra are used for clarification of sugarcane juice. Okra is categorized under often cross-pollinated group and it is an 
interesting crop to the breeders and geneticists for its monodelphous condition of the stamens and large flower amendable to emasculation and high number of seeds production in one pollination. The assessment of variability present in any crop species is an essential prerequite for formulating an effective breeding programme, as the existing variability can be used to enhance the yield level of cultivars following appropriate breeding strategies. The information on heritability alone may not help to identify characters for selection whereas heritability estimates in conjunction with predicted genetic advance is more reliable (Johnson et al., 1955). Heritability provides the information on the magnitude of inheritance of characters from parent to offspring, while genetic advance will be helpful in finding the actual gain expected under selection. Estimation of correlation coefficient among the yield contributing variable is necessary to understand the direction of selection and to maximize yield in the shortest period of time. Genetic correlation indicates the relative importance of character(s) on which greater emphasis should be made in selection for yield. However, as the number of variables in the correlation study increases the direct and indirect association between yield and particular component character becomes complex. It only reveals the direction and magnitude of association between any two characters but the path coefficient analysis helps in partitioning the correlation into direct and indirect effects of various yield components on yield. The success of a systematic breeding programme depends mainly on judicious selection of promising parents from the gene pool, a clear understanding of the genetic mechanism involved in combining ability, heritability, genetic advance and association of different yield attributing characters with yield, which help the breeder in deciding the appropriate breeding procedure towards the genetic potential has been reported by many researchers viz; Reddy et al., (2012), Adiger et al., (2013). Hence, the present investigation was taken up to study the association of yield and its component traits in okra.

\section{Materials and Methods}

The study was conducted at the Vegetable Science Research Farm, Bihar Agricultural University, Sabour, Bhagalpur, Bihar during 2016. The experiment consisted of twenty one hybrids sown in randomized complete block design with three replications. Recommended cultural practices were followed to raise a good crop. The quantitative characters viz. plant height $(\mathrm{cm})$, number of branches per plant, days to first flowering, internodal length $(\mathrm{cm})$, number of nodes per plant, days to $50 \%$ flowering, days to first harvesting, fruit weight $(\mathrm{g})$, number fruit per plant, fruit length $(\mathrm{cm})$, fruit width $(\mathrm{cm})$, seeds per pod, yield per plant $(\mathrm{g})$ The quality parameters viz., ascorbic acid, TSS (Brix) were estimated as per standard procedure.Phenotypic and genotypic coefficients of variation were estimated as per Burton (1952). Genetic advance as percent of mean was estimated according to Johnson et al., (1955). The phenotypic and genotypic correlation coefficient was calculated as per formulae suggested by Al-Jibouri et al., (1958) and Miller et al., (1958). Combining ability was worked out according to procedure suggested by Griffing (1956).

\section{Results and Discussion}

The analysis of variance for combining ability revealed that mean sum of square due to gca (general combining ability) were observed significant for plant height, days to first flowering, fruit width, fruit weight, number of fruits per plant, yield per plant, number of seed per pod, Ascorbic acid content, TSS (Table 1). The mean square due to sca was 
observed significant for fifteen characters. This indicated that both additive and nonadditive gene action played important role for inheritance of these traits. The sca variance component for all the traits indicating the predominance of non-additive gene action for the inheritance of all the traits(Table-1)in turn indicated that there was sufficient variability present in the material studied, which could be utilized in further breeding programme.
The estimation of combining ability parameters for yield, its components and quality traits are presented in Table -2.The range of gca effect for yield per plant was from -5.504 to 12.681.Kashi Kranti out of seven parent namely gave positive effect for this trait. The estimates of gca effect of parents showed that the parent KashiKranti was emerged as good general combiner for yield and yield attributing traits.

Table.1 Analysis of variance for combining ability for 15 characters under study

\begin{tabular}{|l|c|c|c|}
\hline \multicolumn{4}{|c|}{ Mean Sum of Square } \\
\hline Characters & GCA (df=6) & SCA (df=21) & Error (df=54) \\
\hline Plant height (cm) & $25.141^{*}$ & $57.556^{* *}$ & 9.753 \\
\hline $\begin{array}{l}\text { Primary branches/ } \\
\text { plant }\end{array}$ & 0.026 & $0.126^{* *}$ & 0.026 \\
\hline Days to 1st flowering & $0.732^{* *}$ & $0.321^{* *}$ & 0.133 \\
\hline Days to 50\% flowering & 0.119 & $0.178^{* *}$ & 0.217 \\
\hline Days to 1st harvest & 0.440 & $1.582^{* *}$ & 0.261 \\
\hline Internodal length (cm) & 0.315 & $1.833^{*}$ & 0.940 \\
\hline Number of nodes/plant & 0.799 & $3.835^{* *}$ & 0.553 \\
\hline Fruit length (cm) & 0.790 & $1.154^{* *}$ & 0.461 \\
\hline Fruit width (cm) & $0.0044^{* *}$ & $0.010^{* *}$ & 0.001 \\
\hline Fruit weight (g) & $2.029 *$ & $2.241^{* *}$ & 0.659 \\
\hline Number of fruits/plant & $2.993^{*}$ & $3.926^{* *}$ & 1.087 \\
\hline Yield/plant (kg) & $312.438^{* *}$ & $2513.114 * *$ & 28.472 \\
\hline Number of seed/pod & $37.811^{* *}$ & $22.7719 *$ & 10.49 \\
\hline Ascorbic acid (mg/100g) & $1.718^{* *}$ & $2.520^{* *}$ & 0.225 \\
\hline TSS (\%) & $0.023^{* *}$ & $0.025^{* *}$ & 0.006 \\
\hline & & & \\
\hline
\end{tabular}


Table.2 Estimates of gca effects of parents for fifteen characters in okra

\begin{tabular}{|c|c|c|c|c|c|c|c|c|c|c|c|c|c|c|c|}
\hline Source of variation & PH & PB & DFF & D50F & DFH & IL & NP & FL & FrWd & FrW & FrP & YP & SP & $\mathbf{A A}$ & TSS \\
\hline KashiPragati & $2.263^{*}$ & 0.076 & $-0.290 *$ & 0.098 & $-0.323 *$ & 0.186 & 0.306 & 0.070 & -0.004 & 0.239 & -0.299 & -1.619 & $-2.033 *$ & $0.298 *$ & -0.011 \\
\hline ArkaAbhay & 0.330 & 0.040 & $0.324 * *$ & 0.146 & -0.047 & -0.133 & -0.021 & 0.095 & 0.017 & 0.399 & $0.664 *$ & -2.951 & -0.962 & $0.307 *$ & -0.015 \\
\hline Punjab Padmini & -1.225 & -0.056 & -0.062 & -0.098 & 0.096 & 0.079 & -0.067 & 0.122 & 0.007 & 0.238 & 0.043 & -2.382 & 0.645 & $0.573 * *$ & -0.037 \\
\hline PusaSawani & -1.100 & -0.079 & -0.042 & $-0.193=$ & $0.412 *$ & -0.021 & -0.048 & 0.119 & 0.003 & -0.416 & $0.817^{*}$ & $-5.504 * *$ & 1.330 & -0.120 & 0.000 \\
\hline ArkaAnamika & -0.224 & 0.019 & $-0.348 * *$ & 0.036 & -0.040 & -0.033 & -0.218 & -0.241 & $-0.030 * *$ & -0.054 & -0.456 & -0.392 & $-2.722 * *$ & $-0.363 *$ & $0.089 * *$ \\
\hline KashiKranti & $-2.116^{*}$ & -0.015 & 0.003 & 0.026 & -0.016 & -0.310 & $0.462 *$ & 0.372 & $0.033 * *$ & 0.438 & -0.003 & $12.681 * *$ & 0.538 & 0.004 & 0.041 \\
\hline PrabhaniKranti & $2.072 *$ & 0.014 & $0.415 * *$ & -0.014 & -0.082 & 0.232 & -0.414 & $-0.537 *$ & $-0.025^{*}$ & $-0.844 * *$ & $-0.767 *$ & 0.166 & $3.204 * *$ & $-0.699 * *$ & $-0.067 *$ \\
\hline GCA/SCA Ratio & 0.036 & 0.000 & 0.354 & 0.047 & 0.062 & -0.078 & 0.008 & 0.053 & 0.040 & 0.096 & 0.075 & 0.013 & 0.247 & 0.072 & 0.102 \\
\hline
\end{tabular}

Characters:plant height (PH),Number of primary branches/plant(PB), Days to first flowering (DFF), Days to 50\% flowering (D50F), Internodal length(IL), Number of nodes per plant(NP), Days to first harvesting (DFH), Fruit length (FrL), Fruit width (FrWd), Average fruit weight (FrW), Number of fruit/plant (FrP) Yield/plant (YP), Number of seed/pod(SP), Ascorbic acid content(mg/100g), Total soluble solid content $(\%)$.

$*$ (Significant at 5 per cent probability level), ** (Significant at $1 \%$ probability level) 
Table.3 Estimate of sca effects of $F_{1}$ hybrids for fifteen characters in okra

\begin{tabular}{|c|c|c|c|c|c|c|c|c|}
\hline Source of variation & PH & PB & DFF & D50F & DFH & IL & NP & FL \\
\hline KashiPragatix ArkaAbhay & -0.24 & -0.17 & -0.15 & 0.21 & -0.02 & 0.84 & $-1.41 *$ & -0.92 \\
\hline KashiPragati $\times$ Punjab Padmini & 0.42 & $0.80 * *$ & 0.25 & 0.10 & $-1.22 *$ & 0.53 & 0.13 & -0.51 \\
\hline KashiPragati $\times$ PusaSawani & 2.54 & $0.37 *$ & 0.19 & 0.49 & -0.20 & $-2.84 * *$ & $3.27 * *$ & $2.34 * *$ \\
\hline KashiPragati × ArkaAnamika & $15.00 * *$ & $-0.55 * *$ & 0.62 & 0.16 & -0.12 & 0.64 & 0.72 & -0.46 \\
\hline KashiPragati $\times$ KashiKranti & $-8.27 * *$ & -0.04 & -0.01 & -0.30 & -0.13 & 0.39 & 1.04 & -0.39 \\
\hline KashiPragati $\times$ PrabhaniKranti & 5.04 & 0.12 & 0.19 & -0.46 & 0.33 & -0.41 & $1.52 *$ & -0.06 \\
\hline ArkaAbhay $\times$ Punjab Padmini & $-9.51 * *$ & 0.03 & -0.19 & -0.12 & -0.36 & -1.10 & $2.50 * *$ & $1.41 *$ \\
\hline ArkaAbhay $\times$ PusaSawani & -1.23 & $-0.34 *$ & -0.26 & 0.08 & 0.86 & -0.38 & -0.22 & -1.22 \\
\hline ArkaAbhay $\times$ ArkaAnamika & -3.68 & $0.79 * *$ & -0.44 & -0.48 & -0.61 & 0.03 & 0.32 & -0.81 \\
\hline ArkaAbhay $\times$ KashiKranti & $6.45 *$ & $-0.35 *$ & 0.08 & 0.23 & -0.42 & $-2.32 *$ & $2.96 * *$ & $2.08 * *$ \\
\hline ArkaAbhay $\times$ PrabhaniKranti & -3.75 & -0.11 & -0.03 & -0.21 & 0.70 & -0.33 & 0.74 & -0.17 \\
\hline Punjab Padmini $\times$ PusaSawani & $-6.85^{*}$ & -0.08 & $-1.15 * *$ & $-0.83 * *$ & 0.46 & -1.46 & $2.56 * *$ & $1.39 *$ \\
\hline Punjab Padmini $\times$ ArkaAnamika & -3.52 & 0.22 & 0.24 & 0.13 & 0.39 & -0.31 & -0.21 & -0.57 \\
\hline Punjab Padmini $\times$ KashiKranti & $-6.41 *$ & 0.02 & 0.08 & -0.16 & -0.11 & -0.42 & 0.06 & -0.76 \\
\hline Punjab Padmini $\times$ PrabhaniKranti & $7.67 *$ & -0.25 & 0.52 & -0.11 & $1.04 *$ & -0.18 & 0.73 & -0.38 \\
\hline PusaSawani $\times$ ArkaAnamika & 2.39 & $-0.35 *$ & 0.00 & -0.07 & -0.66 & -0.30 & 0.00 & -0.63 \\
\hline PusaSawani $\times$ KashiKranti & $-7.10 *$ & -0.03 & 0.45 & $0.53 *$ & $-1.29 *$ & 0.03 & -1.01 & 0.03 \\
\hline PusaSawani $\times$ PrabhaniKranti & $8.40 * *$ & 0.01 & $1.35 * *$ & $0.96 * *$ & 0.44 & -0.38 & -0.36 & -0.33 \\
\hline ArkaAnamika ×KashiKranti & -3.50 & 0.18 & $-0.83 *$ & -0.03 & -0.46 & -1.35 & $2.21 * *$ & $1.50 *$ \\
\hline ArkaAnamika $\times$ PrabhaniKranti & 0.95 & -0.07 & -0.19 & 0.35 & -0.37 & -0.86 & 0.17 & 0.27 \\
\hline KashiKranti × PrabhaniKranti & $6.58 *$ & $0.32 *$ & -0.18 & -0.25 & 0.69 & 0.55 & -0.74 & 0.34 \\
\hline
\end{tabular}

Characters: Plant height (PH), Number of primary branches / plant (PB), Days to first flowering (DFF), Days to 50\% flowering (D50F), Days to first harvesting (DFH), Internodal length (IL),Number of nodes per plant(NP), FrL(Fruit length).

* (Significant at 5 per cent probability level), ** (Significant at $1 \%$ probability level) 
The parents ArkaAbhay and PusaSawani were found to be best general combiner for fruit per plant, among the parents KashiKranti was emerged to be good general combiner for nodes per plant, fruit width and yield per plant. Among the parents KashiPragati, ArkaAnamika were identified as good general combiner for earliness while PrabhaniKranti and ArkaAbhay for late maturity. The Parent PusaSawani showed negative sca effect for days to $50 \%$ flowering so PusaSawani showed negative gca effect for days to $50 \%$ flowering so PusaSawani was identified as a good general combiner for earliness. The range of scaeffect for this trait was from -12.45 to 69.73.The sca estimates for average fruit width indicated that thirteen cross combinations (KashiPragati x PusaSawani, Punjab Padmini x ArkaAnamika, Punjab Padmini x PrabhaniKranti, ArkaAnamika x KashiKranti, ArkaAnamika x PrabhaniKranti, ArkaAbhay x PrabhaniKranti, PunjabPadmini $x$ PusaSawani) out of 21 crosses were significant(Table-3). The significance of gca and sca variances for these fruits characters indicated that role of both additive and nonadditive gene action for the expression of these characters. These results corroborates with findings of Weerasekara et al., (2008) and Dhabiet al., (2010), Reddy et al., (2012) and Kayande et al., (2018). ArkaAnamika x KashiKranti showed negative significant effect for days to first flowering and positive significant effect for nodes per plant. These crosses involved at least one good general combiner. This is in consonance with the result of Poshiya and Shukla(1986),Vijay and Manohar (1986), Srivastava et al., (1998), Yadav et al., (2007) \& Weerasekara et al., (2008), Pal and Sabesan (2009), Bhatt et al., (2015). The presence of additive gene action would enhance the chances for making improvement through simple selection. Similar type of results were reported by Pandey et al., (2001) and Veermani et al., (2006); Pal and Sabesan et al., (2009, Kumar et al., (2013). From the present study it can be concluded thatAmong the parents Kashi Pragati, Arka Anamika were identified as good general combiner for earliness while Prabhani Kranti and Arka Abhay for late maturity. The parent Pusa Sawani showed negative gca effect for days to $50 \%$ flowering so Pusa Sawani was identified as a good general combiner for earliness. For days to first harvest, the parent Kashi Pragati was identified as good general combiner. Among the parent Prabhani Kranti was identified as good general combiner for seeds per pod.

Arkab Abhay $\times$ Kashi Kranti, Kashi Pragati $\times$ Pusa Sawani, Arka Abhay $\times$ Punjab Padmini, Punjab Padmini $\times$ Pusa Sawani and Arka Anamika $\times$ Kashi Kranti exhibited positive significant effect for yield and yield attributing character fruit length, fruit width, fruit weight, fruit per plant and yield per plant. Arka Abhay $\times$ Kashi Kranti appeared to be cross combination with better sca therefore, these combinations could be exploited in hybrid programme.

\section{References}

Adiger, S., Shanthakumar, G. and Salimath, P.M. 2013. Selection of parents based on combining ability studies in okra (Abelmoschus esculentus (L.) Moench). Karnataka J. Agric. Sci., 26(1):6-9.

Al-Jibouri, H.A., Miller, P.A., Robinson, H. F. (1958): Genetic and environmental variances and covariances in upland cotton cross of interspecific origin. Agron. J., 50: 633-37.

Bhatt, J. P., Kathiria, K.B., Christian, S.S. and Acharya, R.R. (2015). Combining ability studies in okra (Abelmoschus esculentus (L.) Moench) for yield and its component character. Electronic journal of plant breeding, 6(2):479-485.

Dhabi, K.H., Vahhani, J.H., Poshiya, V.K., Jivani, L. and Kcchadia, V.H. (2010) 
.Combining ability for fruit yield and its components over environments in okra (Abelmoschus esculentus (L.) Moench). Res. on crops, 11(2):383-90.

Griffing, B. (1956).Concept of general and specific combining ability in relation to diallel crossing systems. Aust.J.Biol.Sci. 9:463-493.

Johnson, H.W., Robinson, H.F., Comstock, R.E. (1955): Estimation of Genetic variability and environmental variability in soybean. J. Agron., 47:314-318.

Kayande, N.V., Kumbhalkar, H.B. and Shinde, S.(2018). Selection of parents based on combining ability studies in okra (Abelmoschus esculentus L. Moench). International journal of current microbiology and applied sciences, 6:1935-1940

Kumar, A., Baranwal, D.K., Aparna, J. and Srivastava, K. (2013). Combining ability and heterosis for yield and its contributing characters in okra (Abelmoschusesculentus (L.) Moench). Madras agric journal, 100(1-3):30-35.

Pal, A.K. and Sabesan, T. (2009). Combining ability through diallel analysis in okra (Ablemoschus esculentus (L.) Moench). Electronic journal of plant breeding, 1; 84-88.

Pandey, S., Singh, B., Beg, M.Z., Yadav, J.R., Mishra, G. and Sanjeev, Kumar (2008). Heterosis and inbreeding depression in Okra [Ablemoschus esculentus (L.) Moench] Advances in Plant Sciences, 21(1): 129-134.
Poshiya, V.K. and Shukla, P.T. (1986). Heterosis studies in okra (Abelmoschus esculentus (L.) Moench). GAU Res. J., 11(2):21-25.

Reddy, M.T., Haribabu, K., Ganesh, M. and Beguml, H., Reddy, R.S. and Babu, J.D. (2012). Genetic analysis for yield and its components in okra (Abelmoschuses culentus (L.) Moench). Songklanakarin journal of science and technology, 34(2); 133-141.

Srivastava, J.P. and Srivastava, B.P. (1998). Heritability and Genetic Advance in okra (Abelmoschus esculenlus L.). Indian Society of Vegetable Science, Project Directorate of Vegetable Research, Varanasi December 12-14, pp. 15.

Veermani, A. and Vidya, Sagar (2006). Implications of mean performance heterosis and specific combining ability effects on performance of Okra cross. Crop Research, Hisar, 31(2): 288-290.

Weerasekera, D., Jagadeesha, R.C., Wali; M.C., Salimath, P.M., Hosmani, R.M. and Malappanawan, I.K. (2008). Heterosis for yield and yield component in Okra, Karnataka Journal of Agricultural Sciences, 21 (4): 578-579.

Yadav, J.R., Ranjendra, Kumar; Singh, B., Srivastava, J., J.P. RenuYadav and Yadav, R.S. (2007). Combining ability studies in Bhindi. Advances in plant sciences, 20(1): 55-57.

\section{How to cite this article:}

Amba Kumari, Vijay Kumar Singh, M. S. Kundu and Prasad, R. P. 2020. Selection of Parents based on Combining Ability Studies in Okra (Abelmoschus esculentus L. moench). Int.J.Curr.Microbiol.App.Sci. 9(02): 138-144. doi: https://doi.org/10.20546/ijcmas.2020.902.017 